\title{
Effect of ultrasound on different quality parameters of functional sirkencubin syrup
}

\author{
Seydi YIKMIŞ ${ }^{1 *}$
}

\begin{abstract}
Ultrasound is a process studied intensively for different products due to the increasing interest in non-thermal technologies. Sirkencubin syrup contains honey and vinegar and is a functional beverage maintaining health. The aim of this study was to examine the effects of the ultrasound process ( $\mathrm{pH}$, titratable acidity, brix, phenolic compounds, flavonoids, antioxidants, total sugar, HMF, sensory evaluation andmicrobiological) on ultrasonic and functional sirkencubin syrup. Ultrasound treatments (26 kHz frequency, $60 \%$ amplitude, all samples $200 \mathrm{~mL}, 80 \mathrm{~W}$ power) with different times $(2,5,8,10$ and 15 minutes) were applied using an ultrasonic processor. The increase in ultrasound time increased most bioactive compounds compared to control samples (untreated). Significant decreases in microbiological load were also recorded. The results of this study show that the ultrasound process can be used as a suitable technique for processing sirkencubin syrup by increasing the bioactive compounds and maintaining safety and quality standards with general acceptance by panelists.
\end{abstract}

Keywords: ultrasound; sirkencubin syrup; non-thermal; antioxidant; functional.

Practical Application: Treatment of functional sirkencubin syrup with ultrasound and its effects.

\section{Introduction}

During the historical period of Anatolian Seljuks and Principalities, syrup made from a wide variety of fruit and honey or sugar was the most common beverage and source of income (Sahin, 2008). In the period of Mevlana, syrups, jams and compotes were very popular. Sirkencubin is one of the important drinks of Mevlevi cuisine and helps appetite before eating and digestion after dinner. Sirkencubin, made from Persian 'sirke' (vinegar) and 'encubin' (honey), is a very popular drink made from a mixture of honey and vinegar (Özdengül, 2010; Sarıoğlan \& Cevizkaya, 2016).

The popularity of fresh or natural beverages has encouraged studies about natural processing. Thermal pasteurization is a technology used to provide microbial inactivation and to extend the shelf life of fruit juices. However, it causes loss of nutritional and physicochemical parameters. It was reported in studies that quality loss is significant in heat-treated fruit juices such as orange, strawberry and watermelon (Chemat et al., 2011; Rawson et al., 2011). Increased attention to freshness of products has supported efforts to develop innovative non-thermal food preservation methods. Ultrasound is a potential technology abiding by USA Food and Drug Administration (FDA) conditions to ensure a $5-\log$ reduction of foodborne pathogens in fruit juices (Salleh-Mack \& Roberts, 2007).

In studies using ultrasound treatment on liquid foods, important microbial inactivation was reported with promising results of minimal effects on the deterioration of quality parameters and improved functionality (Chemat et al., 2011). Ultrasound treatment of 2 to 6 minutes for carrot-grape juice was determined to significantly increase the total phenolic, flavonoid and antioxidant activity after 90-day storage (Nadeem et al., 2018).
Sonication was found to significantly affect the overall quality of guava juice (Cheng et al., 2007).

When high-frequency ultrasound is emitted in liquid at low frequencies (20 and $100 \mathrm{kHz}$ ), cavitation (formation and collapse of the bubbles) occurs. These bubbles will collapse in the subsequent compression cycles when sound waves are emitted, causing high temperature and pressure zones (O'Donnell et al., 2010). Sonication is simple and reliable, resulting in less processing time and improved productivity.

Ultrasound can be used successfully for sirkencubin syrup to increase the shelf life, ensure the safety, quality and consumer perception without adversely affecting the nutrients. Therefore, bioactive compounds (antioxidants, phenolic compounds, flavonoids) and physicochemical properties ( $\mathrm{pH}, \mathrm{Brix}$, titratable acidity, total soluble solids, total sugar, HMF and color properties) of sirkencubin syrup were evaluated after ultrasound treatment $(0,2,5,8,10$ and $15 \mathrm{~min})$ to determine the effect on microbiological and sensory properties.

\section{Materials and methods}

\subsection{Sirkencubin syrup preparation and ultrasonic processing}

Honey (pine honey) and vinegar (apple vinegar) were purchased from commercial companies. Due to the high bioactive properties of honey, pine honey was preferred (Alpat, 2018). For the syrup mixture, honey (14 g) + vinegar (6 ml) + sterilized water (0.2 liters) was homogenized in an industrial mixer. In this study, total $200 \mathrm{~mL}$ of freshly prepared syrup was processed using a $200 \mathrm{~W}$ ultrasonic processor (Model UP200St, Germany) at a frequency of $26 \mathrm{kHz}$. An ice bath was used to 
control the temperature during the process. The amplitude of the ultrasound device was set to $60 \%$ and a pulsed ultrasound wave was applied to process the syrup. The control sample used was fresh sirkencubin syrup (C). As shown in Table 1, the processing time and operating conditions were set at 2 minutes (US2), 5 minutes (US5), 8 minutes (US8), 10 minutes (US10) and 15 minutes (US15). The samples were stored in glass bottles at a temperature of $-18^{\circ} \mathrm{C}$ until the tests were carried out. All the treatments were carried out in triplicate.

\subsection{Microbiological analysis}

Serial dilutions of syrup were prepared in peptone water solution for the microbial count. Colony forming units (CFU) were determined by standard spreading and pouring plate methodologies. PCA (Plate Count Agar-Merck) was used for total aerobic plate count. Samples were incubated at $30{ }^{\circ} \mathrm{C}$ for $48 \mathrm{~h}$. For yeast and mold count, PDA (Potato Dextrose Agar-Merck) was used. Samples were incubated at $24{ }^{\circ} \mathrm{C}$ for 3-5 days. Total Enterobacteriaceaecount was determined in VRBG (Violet Red BileGlucose Agar-Merck) incubated at $37^{\circ} \mathrm{C}$ for $24 \mathrm{~h}$. Results are given as log colony forming units (CFU) per milliliter of syrup (Cruz et al., 2007).

\section{$2.3 \mathrm{pH}$, Total soluble solids (Brix) and titratable acidity}

Soluble solids were measured using a refractometer (ATAGO brand RX-7000a model, Japan), and pH was measured using a potentiometer (Hanna Instruments HI 2002 $\mathrm{pH} / \mathrm{ORP}$, Romania). Measurements were made at $20^{\circ} \mathrm{C}$ and the results were expressed in Brix. The titration acidity was potentiometrically determined by titration of the samples with $0.1 \mathrm{~N} \mathrm{NaOH}$ solution to $\mathrm{pH} 8.1$ (turning point). Five ml of sample was weighed and $50 \mathrm{ml}$ of distilled water was added with $10 \mathrm{ml}$ sample taken from the filtrate. The volume of $\mathrm{NaOH}$ was converted to $\mathrm{g}$ citric acid per $100 \mathrm{~mL}$ of syrup (Association of Official Analytical Chemists, 1995).

\subsection{Color snalysis}

Color analysis of the samples was made using the Color Measuring Device PCE-CSM 5 (Germany) and liquid container. The color values were expressed as $L^{*}$ (whiteness or brightness/darkness), $a^{*}$ (redness/greenness) and $b^{*}$ (yellowness/blueness). The total color difference (TCD), chroma (C), and hue angle (h) were expressed according to the following Equations 1-3 (Ordóñez-Santos et al., 2017);

Table 1. Parameters of ultrasound treatment for sirkencubin syrup.

\begin{tabular}{cccc}
\hline Sample & Treatment & Time (min) & $\begin{array}{c}\text { Frequency, amplitude (\%) } \\
\text { and power }\end{array}$ \\
\hline \multirow{2}{*}{$200 \mathrm{~mL}$} & US2 & 2 & $26 \mathrm{kHz}, 60,80 \mathrm{~W}$ \\
sirkencubin & US5 & 5 & $26 \mathrm{kHz}, 60,80 \mathrm{~W}$ \\
syrup & US10 & 8 & $26 \mathrm{kHz}, 60,80 \mathrm{~W}$ \\
& US15 & 15 & $26 \mathrm{kHz}, 60,80 \mathrm{~W}$ \\
\hline
\end{tabular}

US2 (sonication for $2 \mathrm{~min}$ ); US5 (sonication for $5 \mathrm{~min}$ ); US8 (sonication for $8 \mathrm{~min}$ ); US10 (sonication for $10 \mathrm{~min}$ ); US15 (sonication for $15 \mathrm{~min}$ ).
$(\mathrm{TCD})=\left((\Delta \mathrm{L})^{2}+(\Delta \mathrm{a})^{2}+(\Delta \mathrm{b})^{2}\right)^{1 / 2}$

Chroma, $\mathrm{C}=\left(\mathrm{a}^{2}+\mathrm{b}^{2}\right)^{1 / 2}$

$\mathrm{h}$ (hue angle $)=\tan ^{-1}(\mathrm{~b} / \mathrm{a})$

\subsection{Total polyphenols, total flavonoids and antioxidant activity}

The total amount of phenolic material was measured spectrophotometrically using the Folin-Ciocalteu method. Gallic acid was used as a reference standard and the results were expressed as mg gallic acid equivalents per liter of sirkencubin syrup (mg GAE/L) (Singleton \& Rossi, 1965). The total flavonoid content was measured with the aluminum chloride colorimetric analysis method. Total flavonoid content was expressed as $\mathrm{mg}$ catechin equivalents (CE) per liter (Zhishen et al., 1999).

The antioxidant activity was measured by the CUPRAC (Cupric Reducing Antioxidant Capacity) test (Apak et al., 2006). Sample of $0.1 \mathrm{ml}$ was added to $1 \mathrm{ml}$ of $0.01 \mathrm{M}$ copper chloride $\left(\mathrm{CuCl}_{2}\right)$, $1 \mathrm{~mL}$ of $7.5 \times 10^{-3}$ Neocuprin (Sigma Aldrich, Germany), $1 \mathrm{~mL}$ of $1 \mathrm{M}$ ammonium acetate solution and $1 \mathrm{~mL}$ of purified water and incubated at $20^{\circ} \mathrm{C}$ for 1 hour. The absorbance was determined with a spectrophotometer (SP-UV/VIS-300SRB, Australia) at $450 \mathrm{~nm}$. Calculations were made by using the standard calibration curve prepared with Trolox (Merck, Germany).

The antioxidant activity of each sample was also estimated using DPPH radical scavenging assay with slight modifications (Blois, 1958). To a known aliquot $(1 \mathrm{~mL})$ of the syrup, $1 \mathrm{~mL}$ of DPPH (1,1-diphenyl 2-picrylhydrazyl) solution $(0.2 \mathrm{mM}$ in methanol) was added, followed by incubation in the dark for $30 \mathrm{~min}$ at room temperature $\left(25 \pm 1^{\circ} \mathrm{C}\right)$. The absorbance changes were determined with a spectrophotometer (SP-UV/VIS-300SRB, Australia) at $517 \mathrm{~nm}$. The DPPH radical scavenging activity was calculated as (Equation 4):

DPPH radical scavenging activity $\left.(\%)=\left(\mathrm{A}_{0}-\mathrm{A}_{1}\right) / \mathrm{A}_{0}\right) \times 100$

where $\mathrm{A}_{0}$ is the absorbance of the control, and $\mathrm{A}_{1}$ is the absorbance of the syrup.

\subsection{Total sugar and hydroxymethyl furfural (HMF)}

The total sugar determination of the samples was carried out using the phenol sulfuric acid method. For the preparation of the samples used in the analysis; $30 \mathrm{mg}$ of sample was taken and $5 \mathrm{~mL}$ of $2.5 \mathrm{~N}$ hydrochloric acid (Merck, Germany) was added and stirred. For hydrolysis, this was left for 3 hours in a water bath of $95^{\circ} \mathrm{C}$ (Wisd ultrasonic water bath, WUC-D06H, Korea) and cooled, and $750 \mu \mathrm{L}$ of $40 \% \mathrm{NaOH}$ was added. Samples were completed to $250 \mathrm{~mL}$ with pure water. Glucose (Merck, Germany) solutions were used as standard. An amount of $600 \mu \mathrm{L}$ of the prepared sample/standard solutions was taken into the test tubes and $600 \mu \mathrm{L}$ of $5 \%$ phenol (Surechem, P1922, UK) solution was added. After stirring, $3 \mathrm{~mL}$ of concentrated sulfuric acid (Merck, Germany) was added and mixed again. The test tubes were kept in a water bath at $80^{\circ} \mathrm{C}$ for 30 minutes. After cooling, absorbance 
values were read with a spectrophotometer (SP-UV/VIS-300SRB, Australia) at $490 \mathrm{~nm}$ wavelength (Nielsen, 2010; Taylor, 1995).

The colorimetric method was used for determination of HMF. This method is based on measurement of HMF with barbituric acid and p-toluene to form a red-colored compound and measuring the resulting color density by the colorimetric method. SP-UV/VIS-300SRB spectrophotometer measured at $550 \mathrm{~nm}$ versus water (LeBlanc et al., 2009).

\subsection{Sensory analysis}

The panelists were asked to evaluate appearance, smell, odor intensity, flavor, color, taste, feel in the mouth, clarity and and overall acceptability of the sirkencubin syrup samples. A total of 10 ( 5 female, 5 male) panelists evaluated the sirkencubin syrup. All samples were randomly coded using three letters (ABE, SDT, ENC, PRY, STR \& XBZ). Scale scores were excellent, 9; very good 8; good, 7; acceptable, 6; and poor (first odorless, tasteless development) $<6$. Acceptance of sub-points was accepted as 6 . The product was described as unacceptable after initial odor or unpleasantness (Petrou et al., 2012).

\subsection{Statistical analysis}

All values were obtained by triplicate and expressed as mean \pm standard deviation (SD). The significant differences between mean values of sirkencubin syrup samples were determined by analysis of variance (one way-ANOVA) using Tukey's HSD (Honestly Significant Difference) test at a significance level of $\mathrm{p}<0.05$. Statistical analysis was conducted using SPSS 22.0 software (SPSS Inc., Chicago, USA). Pearson correlation coefficients were determined using OriginPro version 2017 (OriginLab, Northampton, Massachusetts, USA.).

\section{Results and discussion}

\subsection{Microbiological analysis}

In this study, a significant decrease in the microbial count was observed in sirkencubin syrup samples after sonication and thermal treatment (Table 2). In control sirkencubin syrup, counts of Enterobacteriaceae, Total aerobic bacteria, and yeast and mold were $1.00 \log \mathrm{CFU} / \mathrm{mL}, 2.24 \log \mathrm{CFU} / \mathrm{mL}$ and $2.56 \log \mathrm{CFU} / \mathrm{mL}$, respectively. In comparison with the control sample, total aerobic plate count and yeast and mold count amounts were decreased in the US2 application. For 5, 8, 10 and 15 minute applications, no microbial load was detected in sirkencubin syrup compared to the control sample. Ultrasound treatment was reported to be effective in minimizing the presence of foodborne pathogens in guava, cranberry, grape, pineapple, orange, mango and tomato juices (Adekunte et al., 2010; Bermúdez-Aguirre \& Barbosa-Cánovas, 2012; Cheng et al., 2007; Santhirasegaram et al., 2013; Valero et al., 2007). Reduction in microbial load can be attributed to combined physical and chemical mechanisms that occur during cavitation (Abid et al., 2014). General microbiological analysis were found to be in compliance with Turkish Food Codex Regulation on Microbiological Criteria (Anonymus, 2011).

\section{$3.2 \mathrm{pH}$, Total soluble solids ( $\left.{ }^{\circ} \mathrm{Brix}\right)$ and titratable acidity}

The results on the effect of treatments on $\mathrm{pH}$, titratable acidity (TA), total soluble solids (TSS), and color attributes in sirkencubin syrup are shown in Table 3. In the study, minimal decreases in $\mathrm{pH}$ (3.81-3.78) and TSS (5.10-4.97) were determined. The time period for the ultrasound procedure applied may not be sufficient to disrupt the chemical bonds in the molecular structures of the nutrients contained in liquid food. It can cause minimal changes (Ordóñez-Santos et al., 2017). The minimal changes in $\mathrm{pH}$ values can be attributed to components such as

Table 2. Effect of sonication on microbial inactivation analysis in sirkencubin syrup.

\begin{tabular}{cccc}
\hline Treatment & $\begin{array}{c}\text { Total Enterobacteriaceae count } \\
(\log \text { CFU } / \mathrm{mL})\end{array}$ & $\begin{array}{c}\text { Total aerobic plate count } \\
(\log \text { CFU/mL })\end{array}$ & $\begin{array}{c}\text { Yeast and mold count } \\
(\log \text { CFU/mL })\end{array}$ \\
\hline Control & $1.00 \pm 0.02^{\mathrm{a}}$ & $2.24 \pm 0.01^{\mathrm{a}}$ & $2.56 \pm 0.02^{\mathrm{a}}$ \\
US2 & $\mathrm{ND}$ & $1.00 \pm 0.02^{\mathrm{b}}$ & $<1$ \\
US5 & $\mathrm{ND}$ & $\mathrm{ND}$ & $\mathrm{ND}$ \\
US8 & $\mathrm{ND}$ & $\mathrm{ND}$ & $\mathrm{ND}$ \\
US10 & $\mathrm{ND}$ & $\mathrm{ND}$ & $\mathrm{ND}$ \\
US15 & $\mathrm{ND}$ & $\mathrm{ND}$ & $\mathrm{ND}$ \\
\hline
\end{tabular}

Values followed by different letters within the same column are significantly different ( $\mathrm{p}<0.05)(\mathrm{n}=3 \pm \mathrm{SD})$. ND, not detected; CFU, colony-forming unit; Control (no treatment); US2 (sonication for $2 \mathrm{~min}$ ); US5 (sonication for $5 \mathrm{~min}$ ); US8 (sonication for $8 \mathrm{~min}$ ); US10 (sonication for $10 \mathrm{~min}$ ); US15 (sonication for $15 \mathrm{~min}$ ).

Table 3. Effect of sonication on $\mathrm{pH}$, total soluble solids, titratable acidity and color attributes in sirkencubin syrup.

\begin{tabular}{|c|c|c|c|c|c|c|c|c|c|}
\hline Treat & $\mathrm{pH}$ & TSS ( ${ }^{\circ}$ Brix $)$ & TA (\%) & $L^{*}$ & $a^{*}$ & $b^{*}$ & $\mathrm{C}$ & $\mathrm{h}$ & TCD \\
\hline Con & $81 \pm 0$ & $5.10 \pm 0.00^{\mathrm{a}}$ & $16 \pm 0.00^{\mathrm{a}}$ & $.09 \pm 0$ & $2.30 \pm 0$ & $3.31 \pm$ & $18.13 \pm 0.42^{\mathrm{a}}$ & $47.26 \pm 0.12^{\mathrm{a}}$ & - \\
\hline $\mathrm{U}$ & $3.80 \pm 0.00^{\mathrm{ab}}$ & $5.10 \pm$ & $16=$ & $34.12 \pm 0.29^{a}$ & $12.02 \pm 0.12^{\mathrm{a}}$ & $13.26 \pm 0.11^{\mathrm{a}}$ & $17.56 \pm 0.47^{\mathrm{ab}}$ & $47.79 \pm 0.22^{\mathrm{b}}$ & $0.64 \pm 0.32^{2}$ \\
\hline US5 & & $5.06 \pm 0.06^{\mathrm{ab}}$ & & $33.00 \pm 0.27^{b}$ & $11.39 \pm 0.10^{\mathrm{b}}$ & & $16.95 \pm 0.10^{\mathrm{b}}$ & & \\
\hline US8 & $3.79 \pm 0.00^{\mathrm{ab}}$ & $4.97 \pm 0.06^{\mathrm{b}}$ & $0.16 \pm$ & $31.64 \pm 0.55^{c}$ & $10.70 \pm 0.22^{c}$ & $11.75 \pm 0.21^{b c}$ & $15.89 \pm 0.28^{c}$ & $47.67 \pm 0.37^{\mathrm{b}}$ & $3.33 \pm 0.87^{b}$ \\
\hline US10 & $3.79 \pm 0$ & $4.97 \pm 0.06^{\mathrm{b}}$ & $0.16 \pm 0.01^{\mathrm{a}}$ & $31.06 \pm 0.21^{c}$ & $10.38 \pm 0.13^{c}$ & $11.43 \pm 0.21^{c}$ & $15.44 \pm 0.23^{c}$ & $47.77 \pm 0.25^{\mathrm{b}}$ & $4.05 \pm 0.42^{\mathrm{b}}$ \\
\hline US15 & $.78 \pm 0.01^{b}$ & $4.97 \pm 0.06^{\mathrm{b}}$ & $0.16 \pm 0.01^{\mathrm{a}}$ & $30.87 \pm 0.14^{c}$ & $10.18 \pm 0.28^{c}$ & $11.46 \pm 0.86^{c}$ & $15.58 \pm 0.41^{c}$ & $49.19 \pm 0.16^{\mathrm{b}}$ & $4.31 \pm 0.44^{b}$ \\
\hline
\end{tabular}

Values followed by different letters within the same column are significantly different ( $<<0.05)$ ( $\mathrm{n}=3 \pm$ SD); Control (no treatment); US2 (sonication for 2 min); US5 (sonication for $5 \mathrm{~min}$ ); US8 (sonication for $8 \mathrm{~min}$ ); US10 (sonication for $10 \mathrm{~min}$ ); US15 (sonication for $15 \mathrm{~min}$ ); TA (titratable acidity); TSS (total soluble solids); TCD (total color difference); $\mathrm{C}$ (chroma); h (hue angle). 
organic acids and polyphenols in the product (Sharma et al., 2009). There was no statistically significant change in TA values $(\mathrm{p}>0.05)$. Similar results regarding $\mathrm{pH}$, TA and TSS were reported for ultrasound-treated strawberry, orange, kasturi lime, cranberry, carrot and mango juice (Bhat et al., 2011; Gomes et al., 2017; Jabbar et al., 2014; Santhirasegaram et al., 2013; Tiwari et al., 2008b).

\subsection{Color analysis}

The color of food is one of the most important criteria for the general product acceptance by consumers (Tiwari et al., 2009). In this study, statistically significant differences were observed for all color properties between the control ( $0 \mathrm{~min})$ and sonicated samples $(\mathrm{p}<0.05)$ (Table 3$)$. In the US15 application, L values were determined at the lowest levels. This is in parallel with studies of orange and guava juices (Cheng et al., 2007; Tiwari et al., 2008a). Differences in visual color can be classified according to the total color difference (TCD). The "less noticeable" color change range $(0.5<\mathrm{TCD}<1.5)$ corresponds to a "good-looking" color change $(3.0<\mathrm{TCD}<6.0)$ (Cserhalmi et al., 2006). There were statistically significant differences in TCD values $(p<0.05)$. Oxidation reactions as a result of interaction with free radicals formed during sonication processes (Mason, 1991) and also induced by cavitation during sonication contribute to changes in the color of the product (Cheng et al., 2007; Tiwari et al., 2008c). A further explanation of the reduction in color values may be related to the increase of phenolic compounds in the sonication examples because the vacuole and cell wall release phenolic substances after cavitation breaks the cell wall (Tomadoni et al., 2017). The $\mathrm{L}^{*}$ and $\mathrm{a}^{*}$ decreased as the sonication parameters increased. This confirms the significant negative correlation between $\mathrm{L}^{*}$ and total phenolics $(\mathrm{r}=-0.814)$ and $\mathrm{a}^{*}$ and total flavonoids ( $\mathrm{r}=-0.839)$ (Table 4). However, considering consumer behavior (visual appeal), minor color changes caused by sonication applied to sirkencubin syrup could not be detected with the naked eye. Human eyes cannot perceive these small color variations among samples. Therefore, it is suggested that the sonication technology can be employed for processing of sirkencubin syrup.

\subsection{Total phenols and flavonoids content}

In Table 5, it can be seen that there was a significant increase in total phenols (mg GAE/l) in all the ultrasound-processed sirkencubin syrup samples compared to control. The increase in the total phenolic content in ultrasound sirkencubin syrup samples was US2 $=4.30 \%$, US5 $=7.37 \%$, US $8=7.39 \%$, US $10=13.33 \%$, and US15 $=28.28 \%$ respectively, compared to control. A similar increase in phenolic compounds was also found in grapefruit, carrot, kasturi lime, and Chokanan mango juices after ultrasound treatment (Aadil et al., 2013; Bhat et al., 2011; Jabbar et al., 2014; Santhirasegaram et al., 2013). Phenolic compounds are effective in disease prevention and cancer control due to their strong antioxidant functions (Dranca \& Oroian, 2016). Thus, the increase in total phenols after ultrasound treatment is very useful

Table 4. Pearson's correlation coefficients of phytochemical and color properties of sirkencubin syrup.

\begin{tabular}{|c|c|c|c|c|c|c|c|c|c|c|c|}
\hline & $\begin{array}{c}\text { Total } \\
\text { phenolics }\end{array}$ & $\begin{array}{c}\text { Total } \\
\text { flavonoids }\end{array}$ & $\mathrm{DPPH}$ & CUPRAC & $\begin{array}{l}\text { Total } \\
\text { sugar }\end{array}$ & HMF & $L^{*}$ & $a^{*}$ & $b^{*}$ & C & $\mathrm{h}$ \\
\hline Total phenolics & 1 & & & & & & & & & & \\
\hline Total flavonoids & $0.867^{\star}$ & 1 & & & & & & & & & \\
\hline $\mathrm{DPPH}$ & $0.904^{*}$ & $0.994^{*}$ & 1 & & & & & & & & \\
\hline CUPRAC & $0.973^{*}$ & $0.926^{*}$ & $0.952^{*}$ & 1 & & & & & & & \\
\hline Total sugar & 0.807 & $0.881^{*}$ & $0.885^{\star}$ & $0.910^{*}$ & 1 & & & & & & \\
\hline HMF & $0.902^{*}$ & $0.965^{\star}$ & $0.980^{*}$ & $0.969^{*}$ & $0.949^{*}$ & 1 & & & & & \\
\hline$L^{*}$ & $-0.814^{\star}$ & $-0.969^{\star}$ & $-0.964^{\star}$ & -0.912 & $-0.957^{\star}$ & $-0.980^{*}$ & 1 & & & & \\
\hline$a^{*}$ & $-0.839^{*}$ & $-0.990^{*}$ & $-0.986^{*}$ & $-0.921^{*}$ & $-0.922^{\star}$ & $-0.981^{\star}$ & $0.992^{*}$ & 1 & & & \\
\hline$b^{*}$ & -0.778 & $-0.968^{\star}$ & $-0.957^{\star}$ & $-0.884^{*}$ & $-0.938^{*}$ & $-0.966^{*}$ & $0.997^{\star}$ & $0.992^{*}$ & 1 & & \\
\hline $\mathrm{C}$ & -0.772 & $-0.970^{*}$ & $-0.965^{\star}$ & $-0.872^{*}$ & $-0.891^{*}$ & $-0.959^{*}$ & $0.982^{*}$ & $0.990^{*}$ & $0.989^{*}$ & 1 & \\
\hline $\mathrm{h}$ & $0.950^{*}$ & 0.713 & 0.764 & $0.853^{*}$ & 0.595 & 0.735 & -0.611 & -0.658 & -0.568 & -0.576 & 1 \\
\hline
\end{tabular}

Table 5. Effects of sonication on total phenolics, total flavonoids, DPPH, CUPRAC, total sugar and HMF analysis of sirkencubin syrup.

\begin{tabular}{ccccccc}
\hline Treatment & $\begin{array}{c}\text { Total phenolics } \\
(\mathrm{mg} \mathrm{GAE} / \mathrm{l})\end{array}$ & $\begin{array}{c}\text { Total flavonoids } \\
(\mathrm{mg} \mathrm{CE} / \mathrm{l})\end{array}$ & $\begin{array}{c}\text { DPPH } \\
(\% \text { inhibition })\end{array}$ & $\begin{array}{c}\text { CUPRAC } \\
(\% \text { inhibition })\end{array}$ & $\begin{array}{c}\text { Total sugar } \\
(\mathrm{gr} / \mathrm{l})\end{array}$ & $\begin{array}{c}\text { HMF } \\
(\mathrm{mg} / \mathrm{l})\end{array}$ \\
\hline Control & $77.43 \pm 0.95^{\mathrm{a}}$ & $4.36 \pm 0.71^{\mathrm{a}}$ & $36.57 \pm 0.74^{\mathrm{a}}$ & $57.32 \pm 0.73^{\mathrm{a}}$ & $58.68 \pm 0.24^{\mathrm{a}}$ & $0.83 \pm 0.04^{\mathrm{a}}$ \\
US2 & $80.76 \pm 0.95^{\mathrm{ab}}$ & $5.07 \pm 0.71^{\mathrm{bc}}$ & $39.03 \pm 0.98^{\mathrm{a}}$ & $57.88 \pm 0.76^{\mathrm{a}}$ & $58.72 \pm 0.02^{\mathrm{ab}}$ & $0.87 \pm 0.04^{\mathrm{a}}$ \\
US5 & $83.14 \pm 2.52^{\mathrm{ab}}$ & $6.50 \pm 0.71^{\mathrm{bc}}$ & $41.59 \pm 1.41^{\mathrm{a}}$ & $59.22 \pm 0.84^{\mathrm{ab}}$ & $58.78 \pm 0.32^{\mathrm{ab}}$ & $0.94 \pm 0.04^{\mathrm{a}}$ \\
US8 & $83.62 \pm 0.48^{\mathrm{ab}}$ & $7.21 \pm 0.71^{\mathrm{c}}$ & $43.78 \pm 0.92^{\mathrm{ab}}$ & $60.02 \pm 1.99^{\mathrm{ab}}$ & $58.98 \pm 0.15^{\mathrm{ab}}$ & $1.08 \pm 0.07^{\mathrm{b}}$ \\
US10 & $87.75 \pm 4.50^{\mathrm{b}}$ & $7.69 \pm 0.41^{\mathrm{c}}$ & $45.40 \pm 0.74^{\mathrm{bc}}$ & $62.39 \pm 1.45^{\mathrm{bc}}$ & $59.19 \pm 0.08^{\mathrm{ab}}$ & $1.18 \pm 0.02^{\mathrm{bc}}$ \\
US15 & $99.33 \pm 4.54^{\mathrm{c}}$ & $8.40 \pm 1.09^{\mathrm{c}}$ & $47.76 \pm 0.39^{\mathrm{c}}$ & $65.08 \pm 0.72^{\mathrm{c}}$ & $59.27 \pm 0.05^{\mathrm{b}}$ & $1.26 \pm 0.04^{\mathrm{d}}$ \\
\hline
\end{tabular}

Values followed by different letters within the same column are significantly different (p < 0.05) ( $\mathrm{n}=3 \pm$ SD); Control (no treatment); US2 (sonication for 2 min); US5 (sonication for $5 \mathrm{~min}$ ); US8 (sonication for $8 \mathrm{~min}$ ); US10 (sonication for $10 \mathrm{~min}$ ); US15 (sonication for $15 \mathrm{~min}$ ); DDPH (radical scavenging activity); CUPRAC (Cupric Reducing Antioxidant Capacity); HMF (hidroximetilfurfural). 
for human health. This increase can be attributed to the release of the bound form of the phenolic content due to breakage of the cell wall by the cavitation pressure applied during sonication. Furthermore, the hydroxyl radicals produced by sonication $\left(\mathrm{OH}^{-}\right)$may be due to the addition of the phenolic compounds to the aromatic ring (Aadil et al., 2013). There was no significant correlation between the amount of phenolic substance and total sugar content $(r=0.807)$. However, a positive correlation $(r=0.902)$ was determined with the increase in the amount of HMF (Table 4).

Flavonoids are natural polyphenolic compounds found in plants with a wide range of chemical and biological activity. In epidemiological studies, flavonoids were found to reduce the risk of cardiovascular diseases and cancer (Hertog et al., 1992). In Table 5, it can be seen that there was a significant increase in total flavonoids in all the ultrasound sirkencubin syrup samples compared to control.Increases in ultrasound treated samples were determined according to the control sample. A significant increase in total flavonoids was also observed in ultrasound-treated kasturi lime as well as Chokanan mango juice. (Bhat et al., 2011; Santhirasegaram et al., 2013). Therefore, with the increase in the amounts of phenols and flavonoid after ultrasound application to sirkencubin syrup is advantageous for commercial use and will also be beneficial for the consumer.

\subsection{Total antioxidant capacity}

Table 5 shows the results of antioxidant activity using the DPPH method. There were no statistically significant differences between the control samples and US2 and US5 samples ( $p>0.05$ ). An increase in the amount of antioxidant was detected as the duration of ultrasound increased. The increase in the DPPH (\% inhibition) in ultrasound-processed sirkencubin syrup samples was US2 $=6.73 \%$, US5 $=13.73 \%$, US8 $=19.72 \%$, US10 $=24.15 \%$, and US15 $=30.60 \%$, respectively, compared to control. Similar results were reported in ultrasound-treated purple cactus pear, kasturi lime, grapefruit and corrot-grape juices (Aadil et al., 2013; Bhat et al., 2011; Nadeem et al., 2018; Zafra-Rojas et al., 2013). The result of cavitation induced by sonication can lead to an increase in the amount of phenolic compounds (Aadil et al., 2013).

As shown in Table 5, the CUPRAC (\% inhibition) of all ultrasound-processed sirkencubin syrup showed a significant increase compared to the control sample. It can be seen that the highest percent CUPRAC inhibition was $35.27 \%$ in US15, followed by $19.50 \%$ in US10, $13.88 \%$ in US8, $13.22 \%$ in US5 and $9.98 \%$ in US2, respectively, compared to control samples (21.50\%). When compared to the control sample, statistically significant differences were detected between the sonicated sirkencubin syrup $(\mathrm{p}<0.05)$. In this study, the increased content of the antioxidant capacity of the sonicated sirkencubin syrup may be attributed to ultrasonic-induced cavitation. Many studies reported that color, total phenols and flavonoids could contribute to the antioxidant activity (Baron et al., 2017; Hmid et al., 2017). In this study, the obtained results showed that there was a significant negative correlation between $L^{*}, a^{*}, b^{*}$ and $\mathrm{C}$ values and antioxidant activity (CUPRAC and DPPH) of sirkencubin syrup. A significant positive correlation was found between phenolic and flavonoid substances (Table 4).

\subsection{Total sugar and HMF}

As shown in Table 5, the total sugar (mg/l) of all ultrasoundprocessed sirkencubin syrup showed a significant increase compared to the control sample. The increase in the total sugar in ultrasound sirkencubin syrup samples was US2 $=0.07 \%$, US5 $=0.16 \%$, US $8=0.51 \%$, US $10=0.86 \%$, and US $15=1.00 \%$, respectively, compared to control. When compared to the control sample, statistically significant differences were found between the total sugar $(\mathrm{mg} / \mathrm{l})$ amounts of sonicated sirkencubin syrup $(p<0.05)$. Similar results were reported for ultrasound-treated cantaloupe melon (Cucumis melo L.) and apple juices (Abid et al., 2013; Fonteles et al., 2012). The increase in the amount of sugar can be explained by the breakdown of cells due to ultrasound application which moves sugar from the intracellular cavities into the liquid.

In Table 5, it can be seen that there was a significant increase in $\mathrm{HMF}(\mathrm{mg} / \mathrm{l})$ in all the ultrasound-processed sirkencubin syrup samples compared to control. The increase in the total phenolic content in ultrasound sirkencubin syrup samples was US2 $=4.82 \%$, US5 $=13.25 \%$, US $8=30.12 \%$, US $10=42.17 \%$, and US15 $=51.81 \%$, respectively, compared to control. As a result of the analysis, HMF findings were found to be below $25 \mathrm{mg} / \mathrm{kg}$ determined by AINP (European Fruit Juice Association) and $25 \mathrm{mg} / \mathrm{kg}$ determined by IFFJP (International Federation of Fruit Juice Producers). The effect of increasing the HMF content with the sonication processes is thought to be caused by the maillard reaction. A significant positive correlation $(r=0.949)$ was found between the total sugar content and the amount of HMF (Table 4).

\subsection{Sensory analysis}

As shown in Table 6 and Figure 1, there was no statistically significant change in ultrasound-treated sirkencubin syrup. As for general acceptability, the best result was observed with 8 minutes of application. In the literature, it was determined that the product was generally acceptable in terms of the sensory parameters tested after ultrasound treatment applied to cranberry juice, apple, carrot-grape and orange juice (Jambrak et al., 2017;

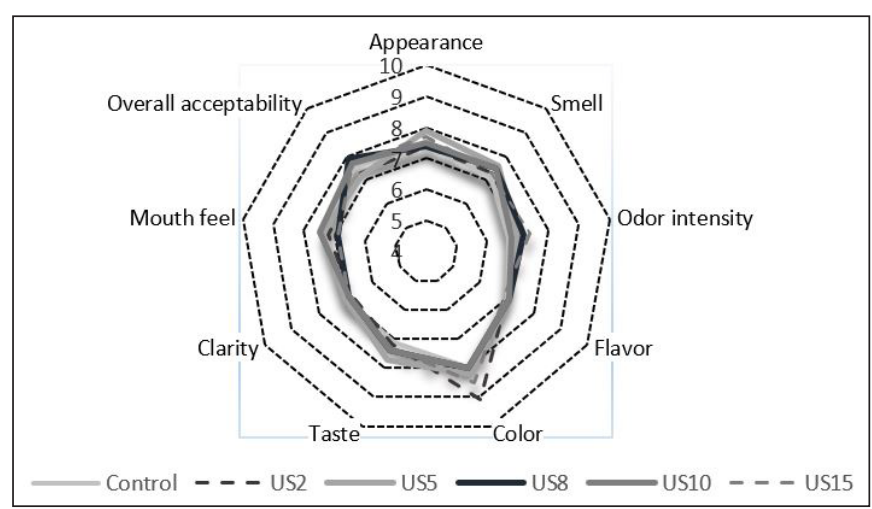

Figure 1. Sensory analysis values chart for treated sirkencubin syrup. 
Table 6. Results of sensory analysis values for treated sirkencubin syrup.

\begin{tabular}{lcccccc}
\hline \multicolumn{1}{c}{ Sensory feature } & Control & US2 & US5 & US8 & US10 & US15 \\
\hline Appearance & $7.40 \pm 0.84^{\mathrm{a}}$ & $7.40 \pm 0.70^{\mathrm{a}}$ & $7.90 \pm 0.74^{\mathrm{a}}$ & $7.40 \pm 0.70^{\mathrm{a}}$ & $7.50 \pm 0.97^{\mathrm{a}}$ & $7.70 \pm 0.67^{\mathrm{a}}$ \\
Smell & $7.20 \pm 0.63^{\mathrm{a}}$ & $7.30 \pm 0.48^{\mathrm{a}}$ & $7.60 \pm 0.70^{\mathrm{a}}$ & $7.50 \pm 0.97^{\mathrm{a}}$ & $7.50 \pm 0.71^{\mathrm{a}}$ & $7.30 \pm 1.06^{\mathrm{a}}$ \\
Odor intensity & $6.70 \pm 0.67^{\mathrm{a}}$ & $7.10 \pm 0.57^{\mathrm{a}}$ & $7.00 \pm 0.82^{\mathrm{a}}$ & $7.20 \pm 0.79^{\mathrm{a}}$ & $6.80 \pm 1.03^{\mathrm{a}}$ & $7.40 \pm 0.84^{\mathrm{a}}$ \\
Flavor & $7.00 \pm 0.67^{\mathrm{a}}$ & $7.00 \pm 0.67^{\mathrm{a}}$ & $7.10 \pm 0.88^{\mathrm{a}}$ & $7.10 \pm 0.99^{\mathrm{a}}$ & $7.10 \pm 0.74^{\mathrm{a}}$ & $6.90 \pm 0.88^{\mathrm{a}}$ \\
Color & $8.00 \pm 0.67^{\mathrm{a}}$ & $9.10 \pm 0.57^{\mathrm{a}}$ & $8.20 \pm 0.79^{\mathrm{a}}$ & $8.00 \pm 0.82^{\mathrm{a}}$ & $8.00 \pm 0.82^{\mathrm{a}}$ & $8.50 \pm 0.71^{\mathrm{a}}$ \\
Taste & $7.10 \pm 0.74^{\mathrm{a}}$ & $7.20 \pm 0.63^{\mathrm{a}}$ & $7.70 \pm 0.95^{\mathrm{a}}$ & $7.40 \pm 0.84^{\mathrm{a}}$ & $7.40 \pm 0.67^{\mathrm{a}}$ & $7.30 \pm 0.67^{\mathrm{a}}$ \\
Mouth feel & $7.00 \pm 0.74^{\mathrm{a}}$ & $6.80 \pm 0.42^{\mathrm{a}}$ & $7.00 \pm 0.67^{\mathrm{a}}$ & $6.90 \pm 0.42^{\mathrm{a}}$ & $6.90 \pm 0.42^{\mathrm{a}}$ & $6.90 \pm 0.70^{\mathrm{a}}$ \\
Clarity & $7.30 \pm 0.48^{\mathrm{a}}$ & $7.20 \pm 0.63^{\mathrm{a}}$ & $7.40 \pm 0.84^{\mathrm{a}}$ & $6.90 \pm 0.99^{\mathrm{a}}$ & $7.50 \pm 0.97^{\mathrm{a}}$ & $6.90 \pm 0.57^{\mathrm{a}}$ \\
Overall acceptability & $7.60 \pm 0.52^{\mathrm{a}}$ & $7.30 \pm 0.82^{\mathrm{a}}$ & $7.20 \pm 0.67^{\mathrm{a}}$ & $7.90 \pm 0.74^{\mathrm{a}}$ & $7.70 \pm 0.95^{\mathrm{a}}$ & $7.70 \pm 0.95^{\mathrm{a}}$ \\
\hline
\end{tabular}

Values followed by different letters within the same column are significantly different ( $\mathrm{p}<0.05$ ) ( $\mathrm{n}=3 \pm$ SD); Control (no treatment); US2 (sonication for 2 min); US5 (sonication for

$5 \mathrm{~min}$ ); US8 (sonication for $8 \mathrm{~min}$ ); US10 (sonication for $10 \mathrm{~min}$ ); US15 (sonication for $15 \mathrm{~min}$ ).

Khandpur \& Gogate, 2015; Nadeem et al., 2018; Samani et al., 2015). Studies have shown that cavitation caused by ultrasound application contributes to the color and taste of fruit juices. The positive effect of the ultrasound process is attributed to the removal of oxygen (Samani et al., 2015). In our study, it was found that in parallel to the literature sensory properties were not affected by the ultrasound process.

\section{Conclusion}

In this study, it was determined that sonication treatment significantly improved the phenolic, flavonoid compounds, color values, and total antioxidant capacity (DPPH and CUPRAC) of sirkencubin syrup without any significant effect on physicochemical parameters ( $\mathrm{pH}$, titratable acidity, $\left.{ }^{\circ} \mathrm{Brix}\right)$. At the same time, HMF levels were determined at reliable levels. In addition, sonication caused a significant reduction in microbial load. The results show that sonication technology can be used successfully for reliable and high quality sirkencubin syrup processing increasing the value to the consumer's health. Combining sonication with other non-thermal food processing technologies to produce improved sirkencubin syrup can provide more possibilities for piloting this new technology. Further research work is required to develop models such as surface response methodology to optimize process variables during sonication processes.

\section{References}

Aadil, R. M., Zeng, X.-A., Han, Z., \& Sun, D.-W. (2013). Effects of ultrasound treatments on quality of grapefruit juice. Food Chemistry, 141(3), 3201-3206. http://dx.doi.org/10.1016/j.foodchem.2013.06.008. PMid:23871078.

Abid, M., Jabbar, S., Hu, B., Hashim, M. M., Wu, T., Lei, S., Khan, M. A., \& Zeng, X. (2014). Thermosonication as a potential quality enhancement technique of apple juice. Ultrasonics Sonochemistry, 21(3), 984-990. http://dx.doi.org/10.1016/j.ultsonch.2013.12.003. PMid:24373787.

Adekunte, A., Tiwari, B., Scannell, A., Cullen, P. J., \& O’Donnell, C. (2010). Modelling of yeast inactivation in sonicated tomato juice. International Journal of Food Microbiology, 137(1), 116-120. http:// dx.doi.org/10.1016/j.ijfoodmicro.2009.10.006. PMid:19906456.

Abid, M., Jabbar, S., Wu, T., Hashim, M. M., Hu, B., Lei, S., Xin, Z., \& Zeng, X. (2013). Effect of ultrasound on different quality parameters of apple juice. Ultrasonics Sonochemistry, 20(5), 1182-1187. http:// dx.doi.org/10.1016/j.ultsonch.2013.02.010. PMid:23522904.
Alpat, U. (2018). Comparison of functional and bioactive properties of pine honey with other important honeys produced in our country. Istanbul: Yildız Technical University.

Anonymus. (2011). Türk Gıda Kodeksi Mikrobiyolojik Kriterler Yönetmeliği. Retrieved from http://www.resmigazete.gov.tr/ eskiler/2011/12/20111229M3-6.htm

Apak, R., Güçlü, K., Özyürek, M., Esin Karademir, S., \& Erçağ, E. (2006). The cupric ion reducing antioxidant capacity and polyphenolic content of some herbal teas. International Journal of Food Sciences and Nutrition, 57(5-6), 292-304. http://dx.doi. org/10.1080/09637480600798132. PMid:17135020.

Association of Official Analytical Chemists - AOAC. (1995). Official methods of analysis (16th ed.). Washington: AOAC.

Baron, M., Kumsta, M., Prusova, B., Tomaskova, L., \& Sochor, J. (2017). Effect of pre-fermentation maceration on the content of antioxidant compounds in grapevine juice. Notulae Botanicae Horti Agrobotanici Cluj-Napoca, 45(1), 105. http://dx.doi.org/10.15835/nbha45110531.

Bermúdez-Aguirre, D., \& Barbosa-Cánovas, G. V. (2012). Inactivation of Saccharomyces cerevisiae in pineapple, grape and cranberry juices under pulsed and continuous thermo-sonication treatments. Journal of Food Engineering, 108(3), 383-392. http://dx.doi.org/10.1016/j. jfoodeng.2011.06.038.

Bhat, R., Kamaruddin, N. S. B. C., Min-Tze, L., \& Karim, A. A. (2011). Sonication improves kasturi lime (Citrus microcarpa) juice quality. Ultrasonics Sonochemistry, 18(6), 1295-1300. http://dx.doi. org/10.1016/j.ultsonch.2011.04.002. PMid:21550834.

Blois, M. S. (1958). Antioxidant determinations by the use of a stable free radical. Nature, 181(4617), 1199-1200. http://dx.doi. org/10.1038/1811199a0.

Chemat, F., Zill-e-Huma, \& Khan, M. K. (2011). Applications of ultrasound in food technology: processing, preservation and extraction. Ultrasonics Sonochemistry, 18(4), 813-835. http://dx.doi. org/10.1016/j.ultsonch.2010.11.023. PMid:21216174.

Cheng, L. H., Soh, C. Y., Liew, S. C., \& Teh, F. F. (2007). Effects of sonication and carbonation on guava juice quality. Food Chemistry, 104(4), 1396-1401. http://dx.doi.org/10.1016/j.foodchem.2007.02.001.

Cruz, N., Capellas, M., Hernández, M., Trujillo, A. J., Guamis, B., \& Ferragut, V. (2007). Ultra high pressure homogenization of soymilk: microbiological, physicochemical and microstructural characteristics. Food Research International, 40(6), 725-732. http:// dx.doi.org/10.1016/j.foodres.2007.01.003.

Cserhalmi, Z., Sass-Kiss, Á., Tóth-Markus, M., \& Lechner, N. (2006). Study of pulsed electric field treated citrus juices. Innovative Food Science \& Emerging Technologies, 7(1-2), 49-54. http://dx.doi. org/10.1016/j.ifset.2005.07.001. 
Dranca, F., \& Oroian, M. (2016). Optimization of ultrasound-assisted extraction of total monomeric anthocyanin (TMA) and total phenolic content (TPC) from eggplant (Solanum melongena L.) peel. Ultrasonics Sonochemistry, 31, 637-646. http://dx.doi.org/10.1016/j. ultsonch.2015.11.008. PMid:26701808.

Fonteles, T. V., Costa, M. G. M., Jesus, A. L. T., Miranda, M. R. A., Fernandes, F. A. N., \& Rodrigues, S. (2012). Power ultrasound processing of cantaloupe melon juice: effects on quality parameters. Food Research International, 48(1), 41-48. http://dx.doi.org/10.1016/j. foodres.2012.02.013.

Gomes, W. F., Tiwari, B. K., Rodriguez, Ó., Brito, E. S., Fernandes, F. A. N., \& Rodrigues, S. (2017). Effect of ultrasound followed by high pressure processing on prebiotic cranberry juice. Food Chemistry, 218, 261-268. http://dx.doi.org/10.1016/j.foodchem.2016.08.132. PMid:27719908.

Hertog, M. G. L., Hollman, P. C. H., \& Katan, M. B. (1992). Content of potentially anticarcinogenic flavonoids of 28 vegetables and 9 fruits commonly consumed in the Netherlands. Journal of Agricultural and Food Chemistry, 40(12), 2379-2383. http://dx.doi.org/10.1021/ jf00024a011.

Hmid, I., Elothmani, D., Hanine, H., Oukabli, A., \& Mehinagic, E. (2017). Comparative study of phenolic compounds and their antioxidant attributes of eighteen pomegranate (Punica granatum L.) cultivars grown in Morocco. Arabian Journal of Chemistry, 10, S2675-S2684. http://dx.doi.org/10.1016/j.arabjc.2013.10.011.

Jabbar, S., Abid, M., Wu, T., Muhammad Hashim, M., Hu, B., Lei, S., Zhu, X., \& Zeng, X. (2014). Study on combined effects of blanching and sonication on different quality parameters of carrot juice. International Journal of Food Sciences and Nutrition, 65(1), 28-33. http://dx.doi.org/10.3109/09637486.2013.836735. PMid:24112293.

Jambrak, A. R., Šimunek, M., Petrović, M., Bedić, H., Herceg, Z., \& Juretić, H. (2017). Aromatic profile and sensory characterisation of ultrasound treated cranberry juice and nectar. Ultrasonics Sonochemistry, 38, 783-793. http://dx.doi.org/10.1016/j.ultsonch.2016.11.027. PMid:28012791.

Khandpur, P., \& Gogate, P. R. (2015). Effect of novel ultrasound based processing on the nutrition quality of different fruit and vegetable juices. Ultrasonics Sonochemistry, 27, 125-136. http://dx.doi. org/10.1016/j.ultsonch.2015.05.008. PMid:26186829.

LeBlanc, B. W., Eggleston, G., Sammataro, D., Cornett, C., Dufault, R., Deeby, T., \& St. Cyr, E. (2009). Formation of Hydroxymethylfurfural in domestic high-fructose corn syrup and its toxicity to the honey bee (Apis mellifera). Journal of Agricultural and Food Chemistry, 57(16), 7369-7376. http://dx.doi.org/10.1021/jf9014526. PMid:19645504.

Mason, T. J. (1991). Practical sonochemistry: user's guide to application in chemistry and chemical engineering. England: Ellis Horwood. https://doi.org/10.1016/J.ULTSONCH.2013.01.021.

Nadeem, M., Ubaid, N., Qureshi, T. M., Munir, M., \& Mehmood, A. (2018). Effect of ultrasound and chemical treatment on total phenol, flavonoids and antioxidant properties on carrot-grape juice blend during storage. Ultrasonics Sonochemistry, 45, 1-6. http://dx.doi. org/10.1016/j.ultsonch.2018.02.034. PMid:29705302.

Nielsen, S. S. (2010). Phenol-sulfuric acid method for total carbohydrates. In S. S. Nielsen. Food analysis laboratory manual (2nd ed., pp. 47-53). Boston: Springer. http://dx.doi.org/10.1007/978-1-4419-1463-7_6.

O’Donnell, C. P., Tiwari, B. K., Bourke, P., \& Cullen, P. J. (2010). Effect of ultrasonic processing on food enzymes of industrial importance. Trends in Food Science \& Technology, 21(7), 358-367. http://dx.doi. org/10.1016/j.tifs.2010.04.007.

Ordóñez-Santos, L. E., Martínez-Girón, J., \& Arias-Jaramillo, M. E. (2017). Effect of ultrasound treatment on visual color, vitamin
C, total phenols, and carotenoids content in Cape gooseberry juice. Food Chemistry, 233, 96-100. http://dx.doi.org/10.1016/j. foodchem.2017.04.114. PMid:28530616.

Özdengül, F. (2010). Bal sirke sirkencubin. Retrieved from https:// faikozdengul.wordpress.com/tag/bal-sirke-sirkencubin/

Petrou, S., Tsiraki, M., Giatrakou, V., \& Savvaidis, I. N. (2012). Chitosan dipping or oregano oil treatments, singly or combined on modified atmosphere packaged chicken breast meat. International Journal of Food Microbiology, 156(3), 264-271. http://dx.doi.org/10.1016/j. ijfoodmicro.2012.04.002. PMid:22534355.

Rawson, A., Patras, A., Tiwari, B. K., Noci, F., Koutchma, T., \& Brunton, N. (2011). Effect of thermal and non thermal processing technologies on the bioactive content of exotic fruits and their products: Review of recent advances. Food Research International, 44(7), 1875-1887. http://dx.doi.org/10.1016/j.foodres.2011.02.053.

Sahin, H. (2008). Türkiye Selçuklu ve Beylikler Dönemi mutfağı (Türkiye Selçuklu ve Beylikler Dönemi Mutfağı). Türk mutfağı. Ankara: TC Kültür ve Turizm Bakanlığı Yayınları.

Salleh-Mack, S. Z., \& Roberts, J. S. (2007). Ultrasound pasteurization: the effects of temperature, soluble solids, organic acids and $\mathrm{pH}$ on the inactivation of Escherichia coli ATCC 25922. Ultrasonics Sonochemistry, 14(3), 323-329. http://dx.doi.org/10.1016/j. ultsonch.2006.07.004. PMid:16965927.

Samani, B. H., Khoshtaghaza, M. H., Lorigooini, Z., Minaei, S., \& Zareiforoush, H. (2015). Analysis of the combinative effect of ultrasound and microwave power on Saccharomyces cerevisiae in orange juice processing. Innovative Food Science \& Emerging Technologies, 32, 110-115. http://dx.doi.org/10.1016/j.ifset.2015.09.015.

Santhirasegaram, V., Razali, Z., \& Somasundram, C. (2013). Effects of thermal treatment and sonication on quality attributes of Chokanan mango (Mangifera indica L.) juice. Ultrasonics Sonochemistry, 20(5), 1276-1282. http://dx.doi.org/10.1016/j.ultsonch.2013.02.005. PMid:23538119.

Sarığlan, M., \& Cevizkaya, G. (2016). Türk Mutfak Kültürü: Şerbetler. Ordu Üniversitesi Sosyal Bilimler Araştırmaları Dergisi, 237-250.

Sharma, H. K., Kaur, J., Sarkar, B. C., Singh, C., \& Singh, B. (2009). Effect of pretreatment conditions on physicochemical parameters of carrot juice. International Journal of Food Science \& Technology, 44(1), 1-9. http://dx.doi.org/10.1111/j.1365-2621.2006.01462.x.

Singleton, V., \& Rossi, A. (1965). Colorimetry of total phenolics with phosphomolybdic-phosphotungstic acid reagent. American Journal of Enology and Viticulture, 16(3), 144-158.

Taylor, K. A. C. C. (1995). A modification of the phenol/sulfuric acid assay for total carbohydrates giving more comparable absorbances. Applied Biochemistry and Biotechnology, 53(3), 207-214. http:// dx.doi.org/10.1007/BF02783496. PMid:8579344.

Tiwari, B. K., Muthukumarappan, K., O’Donnell, C. P., \& Cullen, P. J. (2008a). Colour degradation and quality parameters of sonicated orange juice using response surface methodology. LebensmittelWissenschaft + Technologie, 41(10), 1876-1883. http://dx.doi. org/10.1016/j.lwt.2007.11.016.

Tiwari, B. K., Muthukumarappan, K., O’Donnell, C. P., \& Cullen, P. J. (2008b). Effects of sonication on the kinetics of orange juice quality parameters. Journal of Agricultural and Food Chemistry, 56(7), 2423-2428. http://dx.doi.org/10.1021/jf073503y. PMid:18321054.

Tiwari, B. K., O’Donnell, C. P., Patras, A., \& Cullen, P. J. (2008c). Anthocyanin and ascorbic acid degradation in sonicated strawberry juice. Journal of Agricultural and Food Chemistry, 56(21), 1007110077. http://dx.doi.org/10.1021/jf801824v. PMid:18828602. 
Tiwari, B. K., O’ Donnell, C. P., Muthukumarappan, K., \& Cullen, P. J. (2009). Effect of sonication on orange juice quality parameters during storage. International Journal of Food Science \& Technology, 44(3), 586-595. http://dx.doi.org/10.1111/j.13652621.2008.01858.x.

Tomadoni, B., Cassani, L., Viacava, G., Moreira, M. D. R., \& Ponce, A. (2017). Effect of ultrasound and storage time on quality attributes of strawberry juice. Journal of Food Process Engineering, 40(5), e12533. http://dx.doi.org/10.1111/jfpe.12533.

Valero, M., Recrosio, N., Saura, D., Muñoz, N., Martí, N., \& Lizama, V. (2007). Effects of ultrasonic treatments in orange juice processing.
Journal of Food Engineering, 80(2), 509-516. http://dx.doi.org/10.1016/j. jfoodeng.2006.06.009.

Zafra-Rojas, Q. Y., Cruz-Cansino, N., Ramírez-Moreno, E., DelgadoOlivares, L., Villanueva-Sánchez, J., \& Alanís-García, E. (2013). Effects of ultrasound treatment in purple cactus pear (Opuntia ficus-indica) juice. Ultrasonics Sonochemistry, 20(5), 1283-1288. http://dx.doi.org/10.1016/j.ultsonch.2013.01.021. PMid:23545106.

Zhishen, J., Mengcheng, T., \& Jianming, W. (1999). The determination of flavonoid contents in mulberry and their scavenging effects on superoxide radicals. Food Chemistry, 64(4), 555-559. http://dx.doi. org/10.1016/S0308-8146(98)00102-2. 